\title{
Patterns in the diversity of dragonflies (Odonata) in cities across Central Europe
}

\author{
Christoph WILLIGALLA and Thomas FARTMANN* \\ Department of Community Ecology, Institute of Landscape Ecology, University of Münster, Robert-Koch-Str. 28, \\ 48149 Münster, Germany
}

Key words. Odonata, climate change, environmental gradient, species richness, temperature, urbanisation

\begin{abstract}
Urbanisation is an important cause of species extinctions. Although urban water systems are also highly modified, studies on aquatic or semi-aquatic organisms are rare. The aim of this study is to identify the factors that determine species richness of Odonata in 22 Central European cities and along an urban-rural gradient within six of them. With 64 indigenous species in total and an average of 33 species per city, the species richness of Odonata in Central European cities is comparatively high. A generalised linear model indicates that species richness is positively related to city area. Additional predictors are climatic variables (temperature amplitude, sunshine duration and July temperature) and the year last studied. Since most cities are usually located in areas with naturally high habitat heterogeneity, we assume that cities should be naturally rich in dragonflies. The role of city area as a surrogate for habitat and structural richness most likely explains why it is strongly associated with Odonata species richness. The relationship between species richness and the climatic variables probably reflects that Odonata species richness in Central Europe is limited by warm and sunny conditions more than by availability of water. The temporal effect (the year last studied) on species richness is likely to be a consequence of the recent increase in Mediterranean species associated with global warming. Urbanisation clearly has an adverse effect on the species diversity of Odonata. Species richness increases along a gradient from the centre of a city to the rural area and is significantly highest in rural areas. This pattern probably reflects a gradient of increasing habitat quality from the centre of cities to rural areas. Moreover, the number of water bodies is generally very low in the city centres. Based on our results, we make recommendations for increasing the abundance and number of species of dragonflies in cities.
\end{abstract}

\section{INTRODUCTION}

Despite great conservation efforts during recent decades global biodiversity continues to decrease (Butchart et al., 2010). For terrestrial biomes, land-use change is recognised as the main threat to biological diversity (Sala et al., 2000). Among land-use changes, urbanisation is an important cause of species extinction leading to biotic homogenisation (McKinney, 2006; Grimm et al., 2008). The urban human population is predicted to increase from 3.5 billion in 2010 to 6.3 billion in 2050 (United Nations, 2010). Hence, urban areas are the fastest growing type of land-use worldwide.

Urbanisation leads to a direct loss of natural and seminatural habitats. Moreover, urbanisation alters adjacent undeveloped areas dramatically (McKinney, 2002, 2006). The size of the remaining habitat patches decreases while fragmentation increases (Donnelly \& Marzluff, 2006). Water systems within cities are heavily modified for domestic or industrial use and in order to protect against natural hazards (e.g., floods). Air and surface temperatures are generally higher in cities than in surrounding rural areas (Grimm et al., 2008).

Typically, the effects of urbanisation are greatest in the centres of cities and lowest in the surrounding rural area. However, diversity patterns along urban-rural gradients differ between taxonomic groups (McKinney, 2002, 2008, McDonnell \& Hahs, 2008). Nonetheless, species richness for the vast majority of groups (e.g., vascular plants, birds, mammals, butterflies and other insect groups) is lowest in densely urbanised city centres (McKinney, 2002, 2008). As the numbers of animal species tend to be correlated with plant species richness, species poverty in city centres is a result of sparse vegetation coverage and a low number of plant species in the remaining patches of vegetation (McKinney, 2002). According to McKinney (2008), plants are the only group for which most studies $(\sim 65 \%)$ indicate a peak in species richness in the suburbs. Suburbs are characterised by a high environmental heterogeneity due to a diverse mixture of urban and rural habitats, which are generally associated with high plant species richness (McKinney, 2002, 2008). However, much of the high plant species diversity in the suburbs is attributed to non-native species, which thrive there in the extensive areas of disturbed habitats (e.g. Pyšek, 1988; Celesti-Grapow et al., 2006; Ricotta et al., 2009). In contrast, most of the invertebrate and nonavian vertebrate studies $(\sim 70 \%)$ indicate that species diversity is greatest in rural areas (McKinney, 2008). Marzluff (2001) analysed the bird studies and also finds that two-thirds of them report a peak in diversity in rural areas. McKinney (2008) explains the different diversity patterns between plants and animals in terms of the habitat size needed to maintain viable populations. Plants are able to survive even in small patches, whereas invertebrates and, in particular, vertebrates depend on larger areas for long-term survival.

\footnotetext{
* Author for correspondence; e-mail: fartmann@uni-muenster.de
} 
Most studies on urban ecology involve terrestrial species, such as vascular plants (Zerbe et al., 2003; Cornelis \& Hermy, 2004; Kühn et al., 2004), birds (Cleargeau et al., 1998; Crooks et al., 2003; Chace \& Walsh, 2006) or arthropods (Clark et al., 2007; Niemelä \& Kotze, 2009; Sattler et al., 2010). Although water systems in cities are also highly modified by urbanisation, studies on aquatic or semi-aquatic organisms in urban environments are rare. The few studies available, also report a peak in diversity of aquatic macroinvertebrates in rural areas (Paul \& Meyer, 2001; Walsh et al., 2001; Roy et al., 2003; Urban et al., 2006). However, Vermonden et al. (2009) show that the diversity of aquatic macroinvertebrates in urban water systems is comparable to that in rural areas.

Having a bipartite life cycle with aquatic and terrestrial stages, Odonata are good indicators of habitat quality of both aquatic and terrestrial habitats (Sahlén \& Ekestubbe, 2001; Foote \& Hornung, 2005). On a local scale, the diversity of dragonflies depends on the species richness and structure of aquatic and riparian plants. On a large scale, climate is the main determinant of species richness (Kalkman et al., 2008; Keil et al., 2008).

Since the 1980s, the conditions for Odonata in Central Europe have changed considerably. Due to climate change, temperatures have risen, making conditions more favourable for Mediterranean species and less favourable for northern species (Hickling et al., 2005; Hassall et al., 2007, 2010; Flenner \& Sahlén, 2008; Kalkman et al., 2008; Ott, 2010). Pollution control and more efficient sewage plants have resulted in an improvement in water quality (Gurtner-Zimmermann, 1998; Adams et al., 2001), leading to a recovery of threatened dragonfly species (Kalkman et al., 2008). Moreover, the number of water bodies within cities has increased due to nature conservation and flood protection measures, which has also possibly resulted in an increase there in the diversity of Odonata (Willigalla \& Fartmann, 2010).

The aim of this study is to identify the factors that are associated with Odonata species richness in cities across Central Europe and along urban-rural gradients within cities. We hypothesize that, in general, dragonfly species richness (i) is highest in large cities due to their high habitat heterogeneity, (ii) is affected by climate and (iii) has recently increased possibly due to global warming, enhanced water quality or an increase in the number of water bodies. Moreover, (iv) we assume that Odonata species richness is negatively associated with urbanisation; that is, species richness should decrease along gradients from rural areas to city centres.

\section{MATERIAL AND METHODS}

\section{Data sources and classification}

Species richness across Central Europe

The databases "Odonata" (ÖSTLAP, 2009), "Dokumentation Natur und Landschaft online" (BfN, 2011) and the Web of Science (Thompson Reuters, 2011) were searched for relevant papers using "city" ("stadt"), "urban" ("urban") and "Odonata" ("Libellen") as keywords. In total, we found 214 articles. From this literature on the dragonfly faunas of cities, we selected 22 studies on Central European cities (Fig. 1) that fulfilled the following criteria: (i) the whole city was studied, (ii) the size of the city was greater than $30 \mathrm{~km}^{2}$, (iii) the sampling period was at least 2 years or the number of plots sampled was greater than 10 and (iv) they contained a complete list of all the species recorded.

For all analyses, we used only indigenous species. Species were considered indigenous if they were explicitly classified as indigenous in the paper in question or if the species was recorded at least three times in a city and suitable habitats for the species were present. For further analyses, we differentiated between Mediterranean and Eurasian species according to Sternberg (1998). The different Mediterranean faunal elements (e.g., Atlanto-Mediterranean, Ponto-Mediterranean) were classified as Mediterranean species. All the remaining species (PontoCaspian, Siberian and Eurasian) were classified as Eurasian species, which is a group of species with a more continental distribution (cf. Sternberg, 1998).

\section{Species richness along an urban-rural gradient}

There is data on species richness in all the water bodies in six of the aforementioned 22 cities (Cologne, Gera, Kaiserslautern, Magdeburg, Mayence, Muenster). Sampling intensity in these six cities was comparable; that is, each water body was surveyed four to six times when weather conditions were favourable (warm and sunny days) during the growing season. During each survey both adult dragonflies and exuviae were sampled. Species were classified as indigenous if exuviae, hatching or freshly hatched imagines were observed (Willigalla et al., 2003).

The three city zones in which the water bodies were located are according to McKinney (2002): (i) city centre: $>50 \%$ of the area is covered mainly by multi-storey buildings; (ii) suburbs: between $10 \%$ and $50 \%$ of the area is covered mainly by one- to two-storey buildings; (iii) rural area: $<10 \%$ of the area is covered mainly by single-storey buildings. According to Sternberg \& Buchwald (1999) the water bodies were classified into one of the following eleven types: river, stream, ditch, oxbow lake, lake, gravel pit, natural pond, storm water pond, garden pond, other artificial ponds and puddles. Habitat specificity of Odonata species (Appendix 1) was classified based on their niche breadth (Harabiš \& Dolný, 2010). For this we used Willigalla \& Fartmann (2010) who provide frequency data for all of the eleven types of water body mentioned above and all the species of dragonfly in our data set. Those species that occurred in at most three of these types of water body were classified as habitat specialists. Moreover, we used the differential species criterion of Poniatowski \& Fartmann (2008) to detect further habitat specialists. Species fulfilling the differential species criterion have at least twice the constancy (minimum constancy $20 \%$ ) for a particular type of water body compared to another water type. All species that fulfilled this criterion in at most three different types of water body were also classified as habitat specialists. All other species were defined as habitat generalists.

\section{Statistical analysis}

Species richness across Central Europe

Quasi-Poisson generalised linear models (GLM) (for details, see Crawley, 2007) were used to evaluate the most important parameters associated with species richness of all, Eurasian and Mediterranean Odonata in cities (Table 1). In addition to environmental factors (Table 1), the number of species of dragonfly detected may depend on sampling effort and temporal effects. Accordingly, we controlled for both by integrating "duration of the study" and "last year studied" as predictors in the GLM 


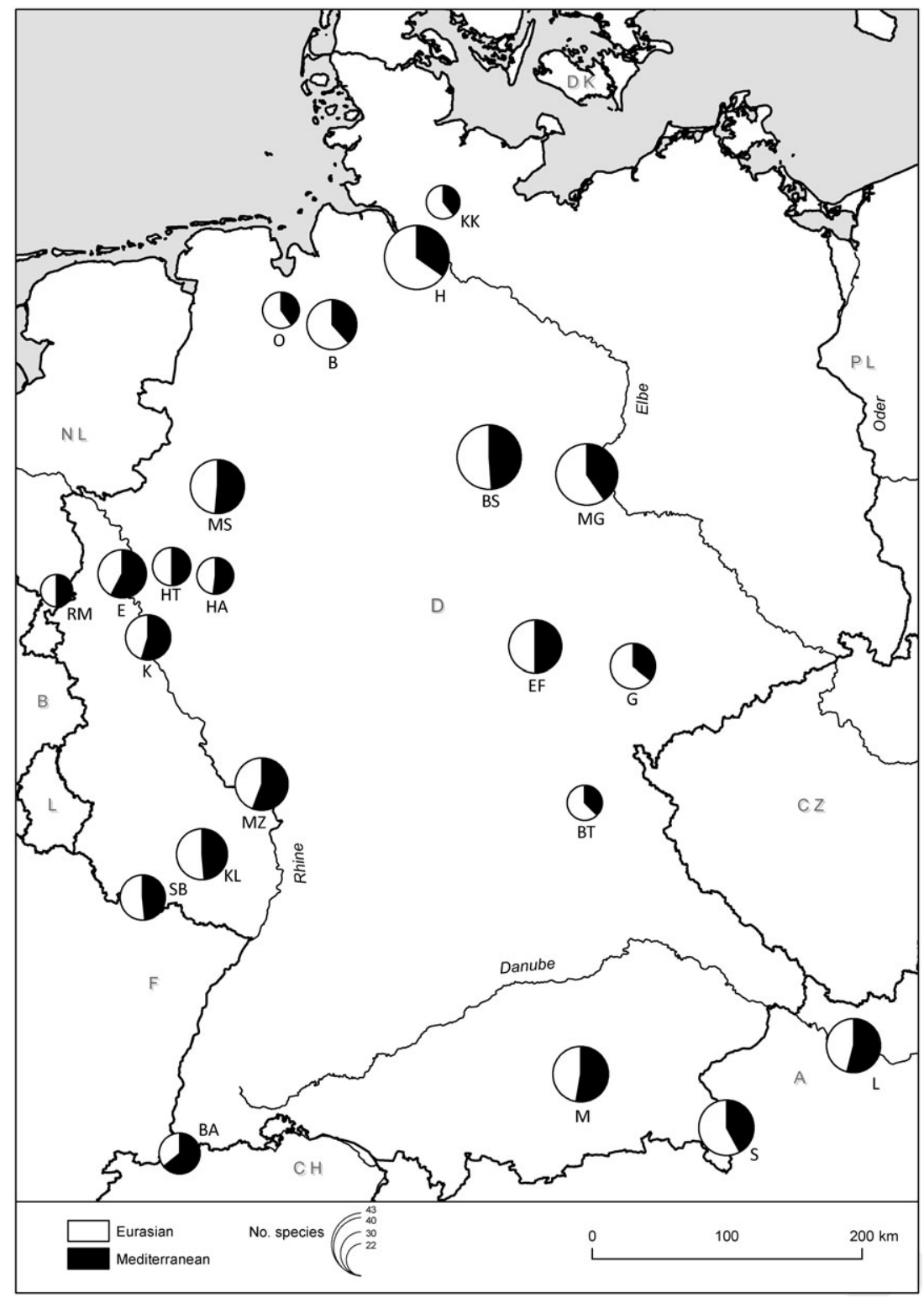

Fig. 1. Species richness in cities in Central Europe. $N_{\text {cities }}=22$. Abbreviations: $\mathrm{B}=$ Bremen, $\mathrm{BA}=\mathrm{Basel}, \mathrm{BS}=\mathrm{Brunswick}, \mathrm{BT}=$ Bayreuth, $\mathrm{E}=$ Essen, $\mathrm{EF}=$ Erfurt $, \mathrm{G}=\mathrm{Gera}, \mathrm{H}=$ Hamburg, $\mathrm{HA}=$ Hagen, $\mathrm{HT}=$ Hattingen, $\mathrm{K}=$ Cologne, $\mathrm{KK}=\mathrm{Kaltenkirchen}, \mathrm{KL}=$ Kaiserslautern, $\mathrm{L}=$ Linz, $\mathrm{M}=$ Munich, $\mathrm{MG}=$ Magdeburg, $\mathrm{MS}=$ Muenster, $\mathrm{MZ}=$ Mayence, $\mathrm{O}=$ Oldenburg, $\mathrm{RM}=\mathrm{Roermond}, \mathrm{S}=$ Salzburg, SB = Saarbrücken. Data sources: Handke et al. (1986), Glitz et al. (1989), Schlumprecht \& Stubert (1989), Breuer et al. (1991), Ott (1993), Laister (1995), Adomßment (1996), Rosenberg et al. (1996), Brux et al. (1998), Artmeyer et al. (2000), Kordges (2000), Schwarz-Waubke \& Schwarz (2000), Bräu et al. (2001), Schlüpmann (2001), Akkermans (2002), Steglich \& Gentz (2002), Willigalla et al. (2003), Jänicke (2004), Bössneck (2005), Conze (2006), Willigalla (2007), Suhling et al. (2009), Küry \& Christ (2010), Menke unpubl. data, Willigalla unpubl. data. Artwork by Franz Löffler.

analysis (Table 1). Moreover, the interaction terms between "city area" and each of the other environmental effects were used as further explanatory variables (e.g. Jarošík et al., 2011, Table 1). Non-significant predictors were excluded from the final model by stepwise backward selection $(P>0.05)$.

Prior to the GLM analysis, inter-correlations between predictor variables were determined using a correlation matrix (Table 1). The collinearity between predictor variables was generally low, with a Spearman rank correlation coefficient $\left(r_{s}\right)$ of $<|0.6|$ for all pairs except city area and duration of the study $\left(r_{s}\right.$ $=0.61, P<0.01)$, altitude and temperature amplitude $\left(r_{s}=0.70\right.$, $P<0.001)$, potential evapotranspiration and temperature $\left(\mathrm{r}_{\mathrm{s}}=\right.$ $0.65, P<0.01)$, potential evapotranspiration and July tempera- ture $\left(r_{s}=0.80, P<0.001\right)$, temperature and July temperature $\left(r_{s}\right.$ $=0.73, P<0.001)$ and actual evapotranspiration and precipitation $\left(r_{s}=0.69, P<0.001\right)$. To avoid problems associated with multicollinearity, actual and potential evapotranspiration, altitude, temperature and duration of the study were deleted from the data set.

Species richness along an urban-rural gradient

As the number of different types of water body per city zone was normally distributed (Kolmogorov-Smirnov test) and variances were homogeneous (Levene's test) an analysis of variance (ANOVA) followed by a Tukey post-hoc test were used to compare the three city zones (Table 1). 
TABLE 1. A list of the parameters and statistical analyses used in this study. Abbreviations: generalised linear model (GLM), generalised linear mixed-effects model (GLMM), analysis of variance (ANOVA), Tukey post-hoc test (TT), Dunn's post-hoc test (DT), Spearman rank correlation $\left(\mathrm{r}_{\mathrm{s}}\right)$. For further information, see Material and methods.

\begin{tabular}{|c|c|c|c|c|}
\hline Parameter & Factor levels & Study part & Mean \pm SE & Min.-Max. \\
\hline \multicolumn{5}{|c|}{ (a) Species richness across Central Europe $\left(N_{\text {cities }}=22\right)^{\mathrm{a}}$} \\
\hline \multicolumn{5}{|l|}{ Response variables } \\
\hline \multicolumn{5}{|l|}{ Species richness } \\
\hline All species & Metric & GLM, $r_{\mathrm{s}}$ & $32.6 \pm 1.4$ & $22-44$ \\
\hline Eurasian species & Metric & GLM, $r_{s}$ & $17.1 \pm 1.0$ & $10-28$ \\
\hline Mediterranean species & Metric & GLM, $\mathrm{r}_{\mathrm{s}}$ & $15.5 \pm 0.8$ & $9-21$ \\
\hline \multicolumn{5}{|l|}{ Predictor variables } \\
\hline \multicolumn{5}{|l|}{ Environmental effects } \\
\hline Altitude (m a.s.1.) & Metric & $r_{s}$ & $176.7 \pm 32.8$ & $3-515$ \\
\hline City area $\left(\mathrm{km}^{2}\right)^{\mathrm{b}}$ & Metric & GLM, $r_{s}$ & $190.0 \pm 34.7$ & $23-755$ \\
\hline Actual evapotranspiration $(\mathrm{mm})^{\mathrm{c}}$ & Metric & $r_{s}$ & $449.6 \pm 13.2$ & $358-560$ \\
\hline Potential evapotranspiration $(\mathrm{mm})^{\mathrm{c}}$ & Metric & $r_{s}$ & $571.6 \pm 15.3$ & $493-739$ \\
\hline Precipitation $(\mathrm{mm})^{\mathrm{c}}$ & Metric & GLM, $r_{s}$ & $769.6 \pm 36.3$ & $458-1169$ \\
\hline Sunshine duration $(\mathrm{h})^{\mathrm{c}}$ & Metric & GLM, $r_{\mathrm{s}}$ & $1533.6 \pm 18.2$ & $1403-1716$ \\
\hline Temperature $\left({ }^{\circ} \mathrm{C}\right)^{\mathrm{c}}$ & Metric & $r_{s}$ & $9.1 \pm 0.2$ & $7.7-10.1$ \\
\hline July temperature $\left({ }^{\circ} \mathrm{C}\right)^{\mathrm{c}}$ & Metric & GLM, $r_{\mathrm{s}}$ & $17.6 \pm 0.2$ & $16.5-19.3$ \\
\hline Temperature amplitude $\left({ }^{\circ} \mathrm{C}\right)^{\mathrm{c}, \mathrm{d}}$ & Metric & GLM, $r_{\mathrm{s}}$ & $17.1 \pm 0.3$ & $15.4-19.9$ \\
\hline \multicolumn{5}{|l|}{ Sampling effects } \\
\hline Duration of the study (years) & Metric & $r_{s}$ & $7.6 \pm 1.7$ & $2-30$ \\
\hline \multicolumn{5}{|l|}{ Temporal effects } \\
\hline Last year studied & Metric & GLM, $r_{\mathrm{s}}$ & $1997.7 \pm 1.6$ & 1986-2009 \\
\hline \multicolumn{5}{|c|}{ (b) Species richness along an urban-rural gradient $\left(N_{\text {cities }}=6\right)^{\mathrm{e}}$} \\
\hline \multicolumn{5}{|c|}{ Response variables } \\
\hline Types of water body/city zone ${ }^{f}$ & Metric & ANOVA, TT & $4.8 \pm 0.7$ & $1-10$ \\
\hline \multicolumn{5}{|l|}{ Species richness } \\
\hline All species & Metric & GLMM, DT, $r_{s}$ & $7.2 \pm 0.3$ & $0-29$ \\
\hline Habitat generalists & Metric & GLMM, DT & $6.3 \pm 0.2$ & $0-21$ \\
\hline Habitat specialists & Metric & GLMM, DT & $0.9 \pm 0.1$ & $0-8$ \\
\hline \multicolumn{5}{|l|}{ Predictor variables } \\
\hline City zone ${ }^{g}$ & 3 & GLMM, DT & . & . \\
\hline \multicolumn{5}{|l|}{ Random factor } \\
\hline City & 6 & GLMM & . & . \\
\hline
\end{tabular}

${ }^{\mathrm{a}}$ Data for all response and predictor variables was obtained from the 22 studies mentioned in Material and methods. The only excep tion is the climate data, which was provided by the German weather service (Deutscher Wetterdienst).

'Besides "city area" we used the interaction terms between "city area" and each of the other environmental effects as further pre dictors.

${ }^{c}$ All climate data, except July temperature and temperature amplitude, are mean annual values (1960-1990).

${ }^{\mathrm{d}}$ Difference between mean July and January temperature.

${ }^{\mathrm{e}}$ Data of all response and predictor variables were obtained from the six studies mentioned in Material and methods.

${ }^{\mathrm{f}}$ Eleven categories according to Sternberg \& Buchwald (1999): river, stream, ditch, oxbow lake, lake, gravel pit, natural pond, st orm water pond, garden pond, other artificial ponds and puddles.

${ }^{g}$ Three categories according to McKinney (2002): city centre, suburb and rural area.

To evaluate if species richness differed among the three city zones, a Poisson generalised linear mixed-effects model (GLMM: lmer, Bates et al., 2008) was used (for details, see Crawley, 2007) (Table 1). To control for potential autocorrelations "city" was set as a random factor. The significance of the predictor variables was assessed using likelihood ratio tests (Type III test). Dunn's test was used as a post-hoc test.

All GLM and GLMM were performed using R-2.9.0 (R Development Core Team, 2009). ANOVA was conducted using SigmaPlot 11.0.

\section{RESULTS}

\section{Species richness across Central Europe}

In the 22 cities included in this study there is a total of 64 species of indigenous Odonata (Appendix 1) of which
$35(55 \%)$ are Eurasian and $29(45 \%)$ are Mediterranean. Average species number per city is $32.6 \pm 1.4$ (SE), comprising $17.1 \pm 1.4$ Eurasian and 15.5 \pm 0.8 Mediterranean species (Table 1). Cities with below average species richness are mostly located in the north-western part of Central Europe (Cologne, Oldenburg, Hagen, Hattingen, Kaltenkirchen and Roermond; Fig. 1). Cities with a low percentage of Mediterranean species $(\leq 40 \%)$ are clustered in northern Central Europe near the North Sea (Bremen, Hamburg, Kaltenkirchen, Oldenburg; Fig. 1).

The quasi-Poisson GLM models showed that the numbers of all (pseudo $R^{2}$ [McFadden] $=0.64$ ), Eurasian (pseudo $R^{2}$ [McFadden] = 0.50) and Mediterranean species (pseudo $R^{2}$ [McFadden] $=0.55$ ) are positively corre- 


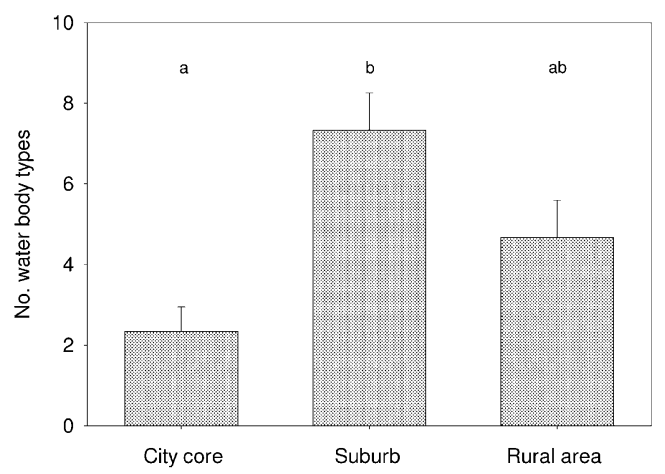

Fig. 2. Number of types of water body in the three city zones (mean $\pm \mathrm{SE}$ ). $N_{\text {cities }}=6$. Anova, $F=9.09, d f=2, P<0.01$. Significant differences $(P<0.05)$ between two zones are marked by different letters (Tukey post-hoc test). Data sources: Ott (1993), Rosenberg et al. (1996), Steglich \& Gentz (2002), Willigalla et al. (2003), Jänicke (2004), Willigalla (2007), Menke unpubl. data, Willigalla unpubl. data.

lated with city area (Table 2). Moreover, species richness of all and Eurasian species increases with temperature amplitude. Further predictors of species richness are the year last studied (all and Mediterranean species), sunshine duration (interaction term with city area; Eurasian species) and July temperature (Mediterranean species); all other variables were excluded from the final model.

\section{Species richness along an urban-rural gradient}

The number of different types of water body in suburbs is significantly higher than in city centres, but not in rural areas (Fig. 2). Species richness of all species, habitat generalists and habitat specialists increases from city centres to rural areas and is significantly higher in the rural area than the two other city zones (Fig. 3).

\section{DISCUSSION}

\section{Species richness across Central Europe}

With 64 indigenous species in total and an average of 33 species per city, Central European cities are characterized by a comparatively high Odonata species richness, containing $79 \%$ and $41 \%$, respectively, of the 81 German species (Ott \& Piper, 1998). The GLM analyses, indicate

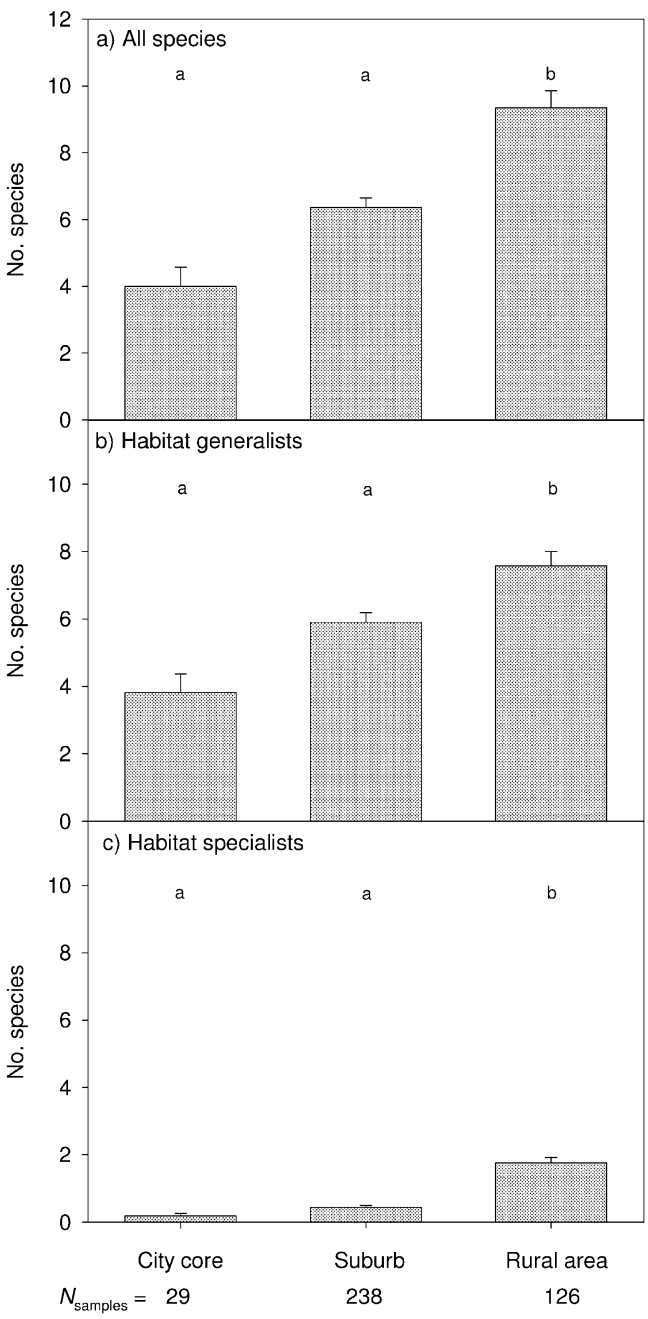

Fig. 3. Number of all species (a), habitat generalists (b) and habitat specialists (c) per water body in the three city zones (mean $\pm \mathrm{SE}$ ). $N_{\text {cities }}=6$. Statistics of GLMM (Poisson response variable) with city as a random factor: (a) all species: $C h i^{2}=$ 136.3, $d f=2, P<0.001$; (b) habitat generalists: $C h i^{2}=66.8, d f$ $=2, P<0.001 ;$ (c) habitat specialists: $C h i^{2}=141.8, d f=2, P<$ 0.001 . Significant differences $(P<0.05)$ between two zones are marked by different letters (Dunn's post-hoc test). Data sources: Ott (1993), Rosenberg et al. (1996), Steglich \& Gentz (2002), Willigalla et al. (2003), Jänicke (2004), Willigalla (2007), Menke unpubl. data, Willigalla unpubl. data.

TABLE 2. Statistics of GLM (quasi-Poisson response variable): Relationships between number of all (a), Mediterranean (b) and Eurasian species (c) and several predictor variables. Non-significant predictors were excluded from the final model by stepwise backward selection $(P>0.05) . N_{\text {cities }}=22$. Data source: see Fig. 1 .

\begin{tabular}{|c|c|c|c|c|}
\hline Variable & Estimate & $\mathrm{SE}$ & $Z$ & $P$ \\
\hline \multicolumn{5}{|l|}{ (a) All species } \\
\hline City area & 0.0009 & 0.0002 & 3.72 & $<0.001$ \\
\hline Temperature amplitude & 0.0716 & 0.0278 & 2.58 & $<0.01$ \\
\hline Last year studied & 0.0098 & 0.0052 & 1.89 & $<0.05$ \\
\hline \multicolumn{5}{|l|}{ Pseudo $R^{2}$ [McFadden] $=0.64$} \\
\hline \multicolumn{5}{|l|}{ (b) Eurasian species } \\
\hline Temperature amplitude & 0.0765 & 0.0383 & 2.00 & $<0.05$ \\
\hline City area $\times$ sunshine duration & 0.0000 & 0.0000 & 3.40 & $<0.001$ \\
\hline \multicolumn{5}{|l|}{ Pseudo $R^{2}$ [McFadden] $=0.50$} \\
\hline \multicolumn{5}{|l|}{ (c) Mediterranean species } \\
\hline City area & 0.0006 & 0.0004 & 1.93 & $<0.05$ \\
\hline July temperature & 0.1415 & 0.0691 & 2.05 & $<0.05$ \\
\hline Last year studied & 0.0168 & 0.0075 & 2.23 & $<0.05$ \\
\hline Pseudo $R^{2}$ [McFadden] $=0.53$ & & & & \\
\hline
\end{tabular}


that species richness of all, Eurasian and Mediterranean species is positively related to the area of a city. Further predictors of species richness are the temperature amplitude (all and Eurasian species), last year studied (all and Mediterranean species), sunshine duration (Eurasian species) and July temperature (Mediterranean species). The explanatory power of the models is generally high with pseudo $R^{2}$ [McFadden] values of $0.50-0.64$.

In contrast to other taxonomic groups (e.g., vascular plants; Kühn et al., 2004), no non-native species of dragonfly or urban exploiters (synanthropes) are known to occur in Central European cities (Willigalla \& Fartmann, 2010). Moreover, there is a decrease in dragonfly species richness with increase in urbanisation (see below), which indicates urbanisation clearly has an adverse effect on the species diversity of Odonata.

However, there are high numbers of species in cities. Most Central European cities are situated on floodplains along large rivers and in areas of high geological diversity (Willigalla \& Fartmann, 2010). In line with Kühn et al. (2004), we assume that there was a high habitat and species richness in these areas prior to their settlement by man. Hence, cities should be naturally rich in dragonflies.

It is well known that the size of an area is among the most important drivers of species richness (Arrhenius, 1921). With increasing area, the likelihood of there being more types of habitat within a defined area increases. According to the habitat heterogeneity hypothesis (cf. Tews et al., 2004), species richness should also increase. Therefore, city area can be considered as a surrogate for habitat and structural richness. Consequently, the number of species of all three groups increases with increasing city area. Some other studies also record an area effect on species richness in human settlements (e.g., Pyšek, 1993; MacGregor-Fors et al., 2011).

Dragonflies are of tropical origin (Pritchard \& Leggott, 1987; Corbet, 1999). Accordingly, diversity increases with temperature from the poles to the equator except in areas with low precipitation (Kalkman et al., 2008). In Central Europe, water is generally widely available due to the moderate, oceanic climate. However, summer temperatures seldom exceed $30^{\circ} \mathrm{C}$ (Ellenberg \& Leuschner, 2010). Hence, temperature rather than precipitation should limit dragonfly diversity. In line with this, dragonfly species richness in Central European cities is related to temperature variables; that is, species richness of all and Eurasian species increases with temperature amplitude, and that of Mediterranean species with July temperature.

Within Central Europe, temperature amplitude strongly increases with longitude and altitude but decreases with latitude; that is, it is lowest in the north-western lowlands and highest in south-eastern Central Europe (Endlicher \& Hendl, 2003). In general, temperature amplitude is a measure of continentality. Continental areas are characterised by warm summers, cold winters and high sunshine duration (Walter \& Breckle, 1994), which are conditions that generally should favour Eurasian species (cf. Eversham \& Cooper, 1998). In line with this, we also observed a positive relationship with sunshine duration (interaction term with city area).

Mediterranean species are highly thermophilic (Sternberg, 1998). Accordingly, the relationship between the species richness of Mediterranean species and July temperature, as a measure for temperature conditions during summer, is not surprising. Areas with the highest July temperatures within Central Europe are the Rhine and Danube Valleys and adjacent areas, and the southern part of the north-eastern lowlands (Müller-Westermeier et al., 1999). These three regions are not only characterized by warm summers, they are among the most important migration corridors for species from southern Europe (Sternberg, 1998), which possibly also accounts for the high numbers of Mediterranean species.

Cities are warmer ("heat islands") than the surrounding landscape (McKinney, 2002; Grimm et al., 2008), conditions that should, in particular, favour high numbers of species of Mediterranean dragonflies. However, the percentage of Mediterranean species is only marginally higher in the cities studied (45\%) than in all of Central Europe (42\%) (cf. Sternberg, 1998). Hence, we assume that for dragonflies the macroclimate is more relevant than the "city climate".

Our analysis indicates that species richness of all and Mediterranean species, but not Eurasian species, is higher the more recent the study. We assume that global warming is the main reason for this increase. A recent range expansion and increase in the species richness of Mediterranean species are documented for Central and Northern Europe (Hickling et al., 2005; Ott, 2010). Negative effects of global warming on northern dragonfly species are also recorded. However, these effects seem to be less pronounced (Hickling et al., 2005; Kalkman et al., 2008; Ott, 2010), which perhaps accounts for the lack of a temporal effect on the species richness of Eurasian species in our data.

Although the number of water bodies in Central European cities has recently increased (Willigalla \& Fartmann, 2010), it is difficult to assess the effect of this on Odonata species richness because data on the quantity and quality of water bodies are missing. However, many of the new water bodies should offer good conditions for Mediterranean species. These water bodies were often designed for nature conservation purposes (e.g., for the European tree frog [Hyla arborea (Linnaeus 1758)] or even dragonflies) or as storm water ponds; both types of water body are ephemeral water bodies that are well exposed to the sun, hence, providing ideal conditions for Mediterranean species of Odonata (e.g., many species of the genus Sympetrum Newmann, 1833; cf. Sternberg \& Buchwald, 2000).

Water quality requirements of Mediterranean and Eurasian species are very similar (Sternberg \& Buchwald, 1999, 2000). Because we observed only a temporal effect in the number of Mediterranean species, improvement in water quality is very unlikely to be the factor determining the increase in their species richness, otherwise there should have also been an increase in the numbers of Eurasian species. Moreover, improvement in water quality has 
occurred mainly in rivers and streams (GurtnerZimmermann, 1998; Adams et al., 2001). However, in Central Europe these particular habitats only make up a small percentage of the potentially suitable habitats for Odonata, and only a few species $(\sim 10)$ are characteristic of rivers and streams (cf. Kuhn \& Burbach, 1998).

In conclusion, although the negative effects of urbanisation on dragonflies clearly dominate over the positive effects, cities still have a rich dragonfly fauna, most likely because they were usually established in areas with high habitat heterogeneity. Because habitat diversity is related to area, dragonfly species richness increases with city size. Under the moderate, oceanic climate conditions in Central Europe, temperature and sunshine duration are also associated with species richness of Odonata; areas with a continental climate (high temperature amplitude, high sunshine duration) promoted Eurasian species, and areas with warm summers (high July temperature) favour Mediterranean species. In general, the macroclimate seems to be more relevant for dragonflies than the "city climate". The recent increase in the species richness of Mediterranean species in the cities studied is possibly a result of global warming. In addition, Mediterranean species were possibly favoured by the construction of new water bodies.

\section{Species richness along an urban-rural gradient}

In this study, habitat diversity and dragonfly species richness is clearly associated with the degree of urbanisation. The number of types of water bodies is highest in the suburbs and significantly differs from that in the city centre but not that in the rural area. In addition, species richness increases along a gradient from the city centre to areas outside the city and is significantly highest in rural areas.

Our results corroborate the findings of the majority of studies on animals along urban-rural gradients with species richness lowest in city centres and peaking in rural areas (see reviews by Marzluff, 2001; McKinney, 2008). However, numbers and types of water bodies alone are poor predictors of the observed pattern in the diversity of dragonflies. Although we have no data on the number of water bodies in each zone of a city, we assume that the number is, like the number of types of water bodies, highest in the suburbs. Swan \& Oldham (1997) show that the conversion of farmland into a housing development led to a net increase in the number of ponds due to the creation of new garden ponds. Because the majority of stormwater ponds following urbanisation are also constructed within the suburbs (Willigalla \& Fartmann, 2009), the number of water bodies should also have increased. In our study, the number of study plots per city zone clearly peaked in the suburbs, where $60 \%$ of all plots were located, which probably also reflects that the number of water bodies is highest in the suburbs.

For a better understanding of the observed pattern, we also have to take into account the quality of the water bodies as well as the quantity and quality of terrestrial habitats for adult Odonata. All of these parameters are assumed to increase along a gradient from the centre of an urbanized area into the surrounding rural area (McKinney, 2002, 2006). Urban water bodies are often intensively managed and poorly designed, and contain high densities of ornamental fish or water birds (Ott, 1995; Swan \& Oldham, 1997). Semi-natural and natural terrestrial habitats, as sites for foraging and thermoregulation of adult dragonflies, are usually small and fragmented in urban areas. Moreover, they are often highly disturbed by human activities (McKinney, 2002, 2006).

We conclude that city centres are characterized by a low number of suitable aquatic and terrestrial habitats for dragonflies and that these habitats are often of low quality. The lack of suitable habitats results in a low species richness of Odonata in general. Although suburbs are characterized by the highest number of different types of water body and probably the highest number of water bodies, the negative effects of human activities on aquatic habitats are high. In addition, the area and quality of the terrestrial habitats might also be low. The peaking of dragonfly species richness in rural areas is most likely because there are more good quality aquatic and terrestrial habitats.

\section{IMPLICATIONS FOR CONSERVATION}

Due to their location on floodplains along large rivers and in areas with high geological diversity, many cities have a high Odonata diversity. Accordingly, cities are generally of interest when considering the conservation of dragonflies. In terms of both the aquatic and terrestrial habitats of dragonflies, nature conservation strategies have to focus on the preservation and restoration of remnant habitats and creation of new habitats.

The construction of garden ponds (Ott, 1993; Bräu et al., 2001; Schlüpmann, 2001) and storm water ponds (Willigalla et al., 2003; Willigalla \& Fartmann, 2009) can considerably increase the species richness of Odonata in an area, especially of the species that are mobile and habitat generalists. Moreover, storm water ponds can act as important habitats for rare pioneer species [e.g., Ischnura pumilio (Charpentier, 1825); Willigalla et al., 2003; Ott, 2008; Willigalla \& Fartmann, 2009]. As Funk et al. (2009) show, floodplain restoration is another way of increasing the number of dragonflies in cities.

Heterogeneous and insect-rich open habitats (e.g., grasslands, verges or forest clearings) that are exposed to the sun and situated in the vicinity of breeding sites are important for foraging and thermoregulation of adult dragonflies (Kuhn \& Burbach, 1998). Hence, conservation should additionally focus on open habitats.

Besides the size and quality of habitat patches, connectivity between water bodies and between water bodies and terrestrial dragonfly habitats is also important. Gledhill et al. (2008) show that in an urban landscape the species richness of hydrophytes and aquatic macroinvertebrates is determined by the number of ponds per unit area. Hence, networks of water bodies and adjacent terrestrial habitats could facilitate migration between water bodies and so improve species persistence (cf. Snep et al., 2006; Bräuniger et al., 2010). 
ACKNOWLEDGEMENTS. We are very grateful to two anonymous referees and M. Konvička for valuable comments on an earlier version of the manuscript.

\section{REFERENCES}

Adams M.S., Ballin U., Gaumert T., Hale B.W., Kausch H. \& KRUSE R. 2001: Monitoring selected indicators of ecological change in the Elbe River since the fall of the Iron Curtain. Environ. Conserv. 28: 333-344.

Adomssment M. 1996: Die Libellen der Stadt Kaltenkirchen, Kreis Segeberg. Die Heimat 11/12: 251-256.

AKKermans R.W. 2002: Libellen in het stedelijk gebied van roermond. Nat. Hist. Maandbl. 91: 103-107.

Arrhenius O. 1921: Species and area. J. Ecol. 9: 95-99.

Artmeyer C., Fronek A., Göcking C., Häusler M., Menke N., Willigalla C. \& Winters S. 2000: Die Libellenfauna der Stadt Münster. Abh. Westfl. Mus. Naturkde Münster/Westfalen 62: 1-73.

Bates D., Maechler M. \& Dai B. 2008: 1me4: Linear mixedeffects models using $\mathrm{S} 4$ classes. $\mathrm{R}$ package version 0.999375-28. http://lme4.r-forge.r-project.org/

BFN (Bundesamt Für Naturschutz) 2011: Dokumentation Natur und Landschaft-online http://www.dnl-online.de/

BöSSNECK U. 2005: Fauna des Stadtgebietes von Erfurt, Teil I: Libellen (Odonata). Veröff. Naturkundemus. Erfurt 24: 109-145.

BräU M., Schwibinger M. \& Weihrauch F. 2001: Die Libellenfauna der Stadt München (Odonata). Nachrichtenbl. Bayer. Entomol. 50: 128-137.

Bräuniger C., Knapp S., Kuhn I. \& Klotz S. 2010: Testing taxonomic and landscape surrogates for biodiversity in an urban setting. Landsc. Urban Plan. 97: 283-295.

Breuer M., Ritzau C., Ruddek J. \& Vogt W. 1991: Die Libellenfauna des Landes Bremen (Insecta: Odonata). Abh. Naturwissenschaftl. Ver. Bremen 41: 479-542.

Brux H., Döring G., Hielscher M., Nordmann M. \& Wiegler G. 1998: Zur Fauna der Stadt Oldenburg: erste Übersicht ausgewählter Gruppen: Säugetiere, Vögel, Reptilien, Amphibien, Libellen, Heuschrecken, Laufkäfer, Schmetterlinge. Oldenbg. Jb. 1998: 247-319.

Butchart S.H.M., Walpole M., Collen B., van Strien A., Scharlemann J.P.W., Almond R.E.A., Baillie J.E.M., Bomhard B., Brown C., Bruno J., Kent E., Carpenter K.E., Carr G.M., Chanson J., Chenery A.M., Csirke J., Davidson N.C., Dentener F., Foster M., Galli A., Galloway J.N., Genovesi P., Gregory R.D., Hockings M., Kapos V., Lamarque J.-F., Leverington F., Loh J., McGeoch M.A., McRae L., Minasyan A., Hernández Morcillo M., Oldfield T.E.E., Pauly D., Quader S., Revenga C., Sauer J.R., Skolnik B., Spear D., Stanwell-Smith D., Stuart S.N., Symes A., Tierney M., Tyrrell T.D., Vié J.-C. \& Watson R. 2010: Global biodiversity: indicators of recent declines. Science 328: $1164-1168$.

Celesti-Grapow L., Pyšek P., JarošíK V. \& Blasi C. 2006: Determinants of native and alien species richness in the flora of Rome. Divers. Distrib. 12: 490-501.

Chace J.F. \& Walsh J.J. 2006: Urban effects on native avifauna: a review. Landsc. Urban Plan. 74: 46-69.

Clark P.J., Reed J.M. \& Chew F.S. 2007: Effects of urbanization on butterfly species richness, guild structure, and rarity. Urban Ecosyst. 10: 321-337.

Conze K.-J. 2006: Die Libellenkartierung der Stadt Essen. Elektr. Aufs. Biol. Station Westl. Ruhrgebiet 6.12: 1-3.

Corbet P. 1999: Dragonflies: Behaviour and Ecology of Odonata. Cornell University Press, Ithaca, 829 pp.
Cornelis J. \& Hermy M. 2004: Biodiversity relationships in urban and suburban parks in Flanders. Landsc. Urban Plan. 69: $385-401$.

Crawley M.J. 2007: The R Book. Wiley, Chichester, 942 pp.

Crooks K.R., Suarez A.V. \& Bolger D.T. 2003: Avian assemblages along a gradient of urbanization in a highly fragmented landscape. Biol. Conserv. 115: 451-462.

Dijkstra K.-D.B. \& Lewington R. 2006: Field Guide to the Dragonflies of Britain and Europe including Western Turkey and North-western Africa. British Wildlife Publishing, Milton on Stour, $320 \mathrm{pp}$.

DonNelly R. \& MARZluff J.M. 2006: Relative importance of habitat quantity, structure, and spatial pattern to birds in urbanizing environments. Urban Ecosyst. 9: 99-117.

Ellenberg H. \& Leuschner C. 2010: Vegetation Mitteleuropas mit den Alpen. 6th ed. Eugen Ulmer, Stuttgart, 1333 pp.

ENDLICHER W. \& HeNDL M. 2003: Klimaspektrum zwischen Zugspitze und Rügen. In Leibniz-Institut für Länderkunde (ed.): Nationalatlas Bundesrepublik Deutschland. Klima, Pflanzen- und Tierwelt. Spektrum, Heidelberg, Berlin, pp. 32-33.

Eversham B.C. \& CoOper J.M. 1998: Dragonfly speciesrichness and temperature: National patterns and latitude trends in Britain. Odonatologica 27: 307-316.

FLENNER I. \& SAHLÉN G. 2008: Dragonfly communities reorganisation in boreal forest lakes: rapid species turnover driven by climate change? Insect Conserv. Divers. 1: 169-179.

Foote A.L. \& Hornung C.L.R. 2005: Odonates as biological indicators of grazing effects on Canadian prairie wetlands. Ecol. Entomol. 30: 273-283.

Funk A., Reckendorfer W., Kucera-Hirzinger V., RaAb R. \& SCHIEMER F. 2009: Aquatic diversity in a former floodplain: Remediation in an urban context. Ecol. Eng. 35: 1476-1484.

Gledhill D.G., James P. \& Davies D.H. 2008: Pond diversity as a determinant of aquatic species richness in an urban landscape. Landsc. Ecol. 23: 1219-1230.

Glitz D., Hohmann H.J. \& PIPeR W. 1989: Artenschutzprogramm Libellen in Hamburg. Naturschutz Landschaftspfl. Hamburg 26: 1-92.

Grimm N.B., Faeth S.H., Golubiewski N.E., Redman C.L., Wu J., BAI X. \& BRIGGS J. 2008: Global change and the ecology of cities. Science 319: 756-760.

Gurtner-Zimmermann A. 1998: The effectiveness of the Rhine Action Program - methodology and results of an evaluation of the impacts of international cooperation. Int. Environ. Aff. 10: $241-266$.

HandKe K., Kalmund P. \& Didion A. 1986: Die Libellen des Saarbrücker Raumes. Libellula 5: 95-112.

Harabiš F. \& DolnÝ A. 2010: Ecological factors determining the density-distribution of Central European dragonflies (Odonata). Eur. J. Entomol. 107: 571-577.

Hassall C., Thompson D.J., French G.C. \& Harvey I.F. 2007: Historical changes in phenology of British Odonata are related to climate change. Glob. Change. Biol. 13: 933-941.

Hassall C., Thompson D.J. \& Harvey I.F. 2010: The impact of climate-induced distributional changes on the validity of biological water quality metrics. Environ. Monit. Assess. 160: 451-456.

Hickling R., Roy D.B., Hill J.K. \& Thomas C.D. 2005: A northward shift of range margins in British Odonata. Glob. Change Biol. 11: 502-506.

JÄNICKE M. 2004: Libellen (Odonata) der Gewässer um Gera. Veröff. Mus. Naturkde Stadt Gera, Naturwiss. R. 31: 57-59. 
Jarošík V., KonvičKa M., Pyšek P., Kadlec T. \& Beneš J. 2011: Conservation in a city: Do the same principles apply to different taxa? Biol. Conserv. 144: 490-499.

Kalkman V.J., Clausnitzer V., DiJkstra K.-D.B., Orr A.G., PaUlson D.R. \& van Tol J. 2008: Global diversity of dragonflies (Odonata) in freshwater. Hydrobiologia 595: 351-363.

Keil P., Simova I. \& Hawkins B. 2008: Water-energy and the geographical species richness pattern of European and North African dragonflies (Odonata). Insect Conserv. Divers. 1: $142-150$.

Kordges T. 2000: Die Libellenfauna der Stadt Hattingen. Der Sauerländische Naturbeobachter 27: 57-66.

Kunn K. \& Burbach K. 1998: Libellen in Bayern. Eugen Ulmer, Stuttgart, $333 \mathrm{pp}$.

Kühn I., BrandL R. \& Klotz S. 2004: The flora of German cities is naturally species rich. Evol. Ecol. Res. 6: 749-764.

KÜRY D. \& ChrIST J. 2010: Die Libellenfauna des Kantons Basel-Stadt. Mitt. Naturforsch. Ges. Basel 12: 105-118.

LAISTER G. 1995: Bestand, Gefährdung und Ökologie der Libellenfauna der Großstadt Linz. Naturkundl. Jb. Stadt Linz 40/41: 9-305.

MacGregor-Fors I., Morales-Perez L. \& Schondube J.E. 2011: Does size really matter? Species-area relationships in human settlements. Divers. Distrib. 17: 112-121.

MarzLufF J.M. 2001: Worldwide urbanization and its effects on birds. In Marzluff J.M., Bowman R. \& Donnelly R. (ed.): Avian Conservation and Ecology in an Urbanizing World. Kluwer Academic Press, Norwell, pp. 21-47.

McKinney M.L. 2002: Urbanization, biodiversity, and conservation. BioScience 52: 883-890.

McKinNeY M.L. 2006: Urbanization as a major cause of biotic homogenization. Biol. Conserv. 127: 247-260.

McKinNeY M.L. 2008: Effects of urbanization on species richness: A review of plants and animals. Urban Ecosyst. 11: 161-176.

McDonnell M.J. \& Hahs A.K. 2008: The use of gradient analysis studies in advancing our understanding of the ecology of urbanizing landscapes: current status and future directions. Landsc. Ecol. 23: 1143-1155.

Müller-Westermeier G., Kreis A. \& Dittmann E. 1999: Klimaatlas Bundesrepublik Deutschland. Vol. 1, Lufttemperatur, Niederschlagshöhe, Sonnenscheindauer. Deutscher Wetterdienst, Offenbach, 23 pp.

NiEmelä J. \& Kotze C.J. 2009: Carabid beetle assemblages along urban to rural gradients: A review. Landsc. Urban Plan. 92: $65-71$.

ÖSTLAP 2009: Literaturdatenbank Libellen. Ökologische Studien, Landschaft, Planung, M. Schorr, Zerf. Dragonfly Res. 7.

Oтт J. 1993: Die Libellenfauna der Stadt Kaiserslautern Ergebnisse einer Stadtbiotopkartierung und planerische Konsequenzen. Fauna Flora Rheinland-Pfalz 7: 103-146.

Отт J. 1995: Zum Einfluß intensiver Freizeit- und Angelnutzung auf die Fauna von Sekundärgewässern und Konsequenzen für die Landschaftsplanung - dargestellt am Beispiel der Libellen (Odonata). Fauna Flora Rheinland-Pfalz 8: 147-184.

Отт J. 2008: Die Kleine Pechlibelle - Ischnura pumilio (Charpentier, 1925) (Odonata: Coenagrionidae) in der Pfalz - ein Profiteur von Regenrückhaltebecken, Naturschutzgewässern und der Klimaänderung. Mainzer Naturw. Arch. 46: 233-261.

Отт J. (ed.) 2010: Monitoring Climatic Change with Dragonflies. BioRisk 5. Pensoft, Sofia-Moscow, 286 pp.

OTT J. \& PIPER W. 1998: Rote Liste der Libellen (Odonata) (Bearbeitungsstand 1997). Schriftenr. Landschaftspfl. Naturschutz 55: 260-263.
Paul M.J. \& Meyer J.L. 2001: Streams in the urban landscape. Annu. Rev. Ecol. Syst. 32: 333-365.

Poniatowski D. \& Fartmann T. 2008: The classification of insect communities: Lessons from orthopteran assemblages of semi-dry calcareous grasslands in central Germany. Eur. J. Entomol. 105: 659-671.

Pritchard G. \& Leggott M.A. 1987: Temperature, incubation rates and origins of dragonflies. Adv. Odonatol. 3: 121-126.

PYŠEK P. 1989: On the richness of Central European urban flora. Preslia 61: 329-334.

PYŠEK P. 1993: Factors affecting the diversity of flora and vegetation in central European settlements. Vegetatio 106: 89-100.

R Development Core Team 2009: R: A Language and Environment for Statistical Computing. http://www.R-project.org.

Ricotta C., La Sorte F.A., Pyšek P., Rapson G.L., CelestiGrapow L. \& Thompson K. 2009: Phyloecology of urban alien floras. J. Ecol. 97: 1243-1251.

Rosenberg J., Kreul K. \& Schlurmann M. 1996: Untersuchungen zur Libellenfauna (Insecta, Odonata) an ausgewählten Standorten der Stadt Köln. Decheniana (Beih.) 35: 25-41.

Roy A.H., Rosemond A.D., Paul M.J., Leigh D.S. \& Wallace J.B. 2003: Stream macroinvertebrate response to catchment urbanisation (Georgia, USA). Freshw. Biol. 48: 329-346.

SAHLEN G. \& Ekestubbe K. 2001: Identification of dragonflies (Odonata) as indicators of general species richness in boreal forest lakes. Biodiv. Conserv. 10: 673-690.

Sala O.E., Chapin F.S., Armesto J.J., Berlow E., Bloomfield J., Dirzo R., Huber-Sanwald E., Huenneke L.F., Jackson R.B., Kinzig A., Leemans R., Lodge D.M., Mooney H.A., Oesterheld M., Poff N.L., Sykes M.T., Walker B.H., WALKER M. \& WALL D.H. 2000: Biodiversity - global biodiversity scenarios for the year 2100. Science 287: 1770-1774.

Sattler T., Duelli P., Obrist M.K., Arletaz R. \& Moretti M. 2010: Response of arthropod species richness and functional groups to urban habitat structure and management. Landsc. Ecol. 25: 941-954.

Schlumprecht H. \& Stubert I. 1989: Libellen im Stadtgebiet Bayreuth I. Vorkommen, Verteilung, Gefährdung. Libellula 8: $157-171$.

SCHLÜPMANN M. 2001: Die Libellenfauna urbaner Lebensräume am Beispiel der Stadt Hagen. Dortmunder Beitr. Landeskde 35: 191-216.

Schwarz-WaubKe M. \& Schwarz M. 2000: Die Libellenfauna im Stadtgebiet von Salzburg (Österreich) - Ergebnisse einer Biotopkartierung aus den Jahren 1994-1995. Linzer Biol. Beitr. 32: 1093-1162.

Snep R.P.H., Opdam P.F.M., Baveco J.M., WallisDeVries M.F., Timmermans W., KwaK R.G.M. \& Kuypers V. 2006: How peri-urban areas can strengthen animal populations within cities: A modeling approach. Biol. Conserv. 127: 345-355.

Steglich R. \& Genz P.-L. 2002: Libellenatlas Landeshauptstadt Magdeburg. Umweltamt, Magdeburg, 112 pp.

Sternberg K. 1998: The postglacial colonization of Central Europe by dragonflies, with special reference to southwestern Germany (Insecta, Odonata). J. Biogeogr. 25: 319-337.

Sternkerg K. \& Buchwald R. (ed.) 1999: Die Libellen BadenWürttembergs. Vol. 1, Allgemeiner Teil, Kleinlibellen (Zygoptera). Eugen Ulmer, Stuttgart, 468 pp.

Sternnerg K. \& Buchwald R. (ed.) 2000: Die Libellen BadenWürttembergs. Vol. 2, Großlibellen (Anisoptera). Eugen Ulmer, Stuttgart, $712 \mathrm{pp}$.

Suhling F., Martens A., Leipelt K.G., Schütte C. \& HoppeDominIK B. 2009: Libellen Braunschweigs - Verbreitungs- 
muster und Bestandstrends der Libellenfauna einer Großstadt (Odonata). Braunschw. Naturkundl. Schr. 8: 449-476.

Swan M.J.S. \& Oldham R.S. 1997: Pond loss and amphibians: a historical perspective. In Boothby J. (ed.): British Pond Landscape: Action for Protection and Enhancement. UK Conference of the Pond Life Project, University College Chester, 7-9 September 1997. Pond Life Project, Liverpool, pp. 3-16.

Tews J., Brose U., Grimm V., Tielbörger K., Wichmann M.C., Schwager M. \& Jeltsch F. 2004: Animal species diversity driven by habitat heterogeneity/diversity: the importance of keystone structures. J. Biogeogr. 31: 79-92.

ThOMPSON Reuters 2011: Web of Science. http://www.apps. isiknowledge.com

United Nations 2010: World Urbanization Prospects: The 2009 Revision. United Nations, New York, 44 pp.

Urban M.C., Skelly D.K., Burchsted D., Price W. \& Lowry S. 2006: Stream communities across a rural-urban landscape gradient. Divers. Distrib. 12: 337-350.

Vermonden K., Leuven R.S.E.W., van der Velde G., van KatwiJK M.M., Roelofs J.G.M. \& HeNDRIKS A.J. 2009: Urban drainage systems: An undervalued habitat for aquatic macroinvertebrates. Biol. Conserv. 142: 1105-1115.

Walsh C.J., Sharpe A.K., Breen P.F. \& Sonneman J.A. 2001: Effects of urbanization on streams of the Melbourne region,
Victoria, Australia. I. Benthic macroinvertebrate communities. Freshw. Biol. 46: 535-551.

Walter H. \& Breckle S.-W. 1994: Ökologie der Erde. Vol. 3, Spezielle Ökologie der Gemäßigten und Arktischen Zonen Euro-Nordasiens. 2. ed. G. Fischer, Stuttgart, Jena, 401 pp.

WiLligalla C. 2007: Zusammensetzung der Libellenfauna der Stadt Mainz im Zeitraum der letzten 30 Jahre (Insecta: Odonata). Fauna Flora Rheinland-Pfalz 11: 175-190.

Willigalla C. \& Fartmann T. 2009: Die Libellenfauna der Regenrückhaltebecken der Stadt Mainz (Odonata). Libellula 28: $117-137$.

Willigalla C. \& Fartmann T. 2010: Libellen-Diversität und -Zönosen in mitteleuropäischen Städten - ein Überblick. Naturschutz Landschaftspl. 42: 341-350.

Willigalla C., Kronshage A. \& Menke N. 2003: Naturschutzbedeutung von Regenrückhaltebecken - Dargestellt am Beispiel der Libellen in Münster/Westfalen. Naturschutz Landschaftspl. 35: 83-89.

Zerbe S., Maurer U., Schmitz S. \& Sukopp H. 2003: Biodiversity in Berlin and its potential for nature conservation. Landsc. Urban Plan. 62: 139-148.

Received August 11, 2011; revised and accepted November 15, 2011 
Appendix 1. Constancy (\%) of indigenous species of Odonata in Central European cities. $N_{\text {cities }}=22$. Data source: see Fig. 1 . Classification of habitat specificity: see Data sources and classification. Scientific nomenclature follows Dijkstra \& Lewington (2006).

\begin{tabular}{|c|c|c|}
\hline Species & Habitat specificity & Constancy $(\%)$ \\
\hline \multicolumn{3}{|l|}{ Zygoptera } \\
\hline Calopteryx splendens (Harris, 1782) & specialist & 86 \\
\hline Calopteryx virgo (Linnaeus, 1758) & specialist & 64 \\
\hline Ceriagrion tenellum (de Villers, 1789) & specialist & 9 \\
\hline Coenagrion hastulatum (Charpentier, 1825) & specialist & 18 \\
\hline Coenagrion lunulatum (Charpentier, 1840) & specialist & 9 \\
\hline Coenagrion mercuriale (Charpentier, 1840) & specialist & 18 \\
\hline Coenagrion puella (Linnaeus, 1758) & generalist & 100 \\
\hline Coenagrion pulchellum (Vander Linden, 1825) & specialist & 45 \\
\hline Enallagma cyathigerum (Charpentier, 1840) & generalist & 100 \\
\hline Erythromma lindenii (Selys, 1840) & generalist & 32 \\
\hline Erythromma najas (Hansemann, 1823) & specialist & 77 \\
\hline Erythromma viridulum (Charpentier, 1840) & generalist & 73 \\
\hline Ischnura elegans (Vander Linden, 1820) & generalist & 100 \\
\hline Ischnura pumilio (Charpentier, 1825) & specialist & 68 \\
\hline Lestes barbarus (Fabricius, 1798) & specialist & 41 \\
\hline Lestes dryas Kirby, 1890 & specialist & 59 \\
\hline Lestes sponsa (Hansemann, 1823) & generalist & 95 \\
\hline Lestes virens (Charpentier, 1825) & specialist & 36 \\
\hline Lestes viridis (Vander Linden, 1825) & generalist & 100 \\
\hline Platycnemis pennipes (Pallas, 1771) & generalist & 91 \\
\hline Pyrrhosoma nymphula (Sulzer, 1776) & generalist & 100 \\
\hline Sympecma fusca (Vander Linden, 1820) & generalist & 64 \\
\hline \multicolumn{3}{|l|}{ Anisoptera } \\
\hline Aeshna affinis Vander Linden, 1820 & specialist & 18 \\
\hline Aeshna cyanea (Müller, 1764) & generalist & 100 \\
\hline Aeshna grandis (Linnaeus, 1758) & generalist & 68 \\
\hline Aeshna isoceles (Müller, 1767) & specialist & 32 \\
\hline Aeshna juncea (Linnaeus, 1758) & specialist & 45 \\
\hline Aeshna mixta Latreille, 1805 & generalist & 100 \\
\hline Aeshna subarctica Walker, 1908 & specialist & 9 \\
\hline Aeshna viridis Eversmann, 1836 & specialist & 14 \\
\hline Anax ephippiger (Burmeister, 1839) & specialist & 5 \\
\hline Anax imperator Leach, 1815 & generalist & 100 \\
\hline Anax parthenope (Selys, 1839) & specialist & 18 \\
\hline Brachytron pratense (Müller, 1764) & specialist & 41 \\
\hline Cordulegaster bidentata Selys, 1843 & specialist & 14 \\
\hline Cordulegaster boltonii (Donovan, 1807) & specialist & 27 \\
\hline Cordulia aenea (Linnaeus, 1758) & generalist & 82 \\
\hline Crocothemis erythraea (Brullé, 1832) & specialist & 36 \\
\hline Gomphus flavipes (Charpentier, 1825) & specialist & 9 \\
\hline Gomphus pulchellus Selys, 1840 & generalist & 50 \\
\hline Gomphus vulgatissimus (Linnaeus, 1758) & specialist & 45 \\
\hline Leucorrhinia albifrons (Burmeister, 1839) & specialist & 5 \\
\hline Leucorrhinia dubia (Vander Linden, 1825) & specialist & 27 \\
\hline Leucorrhinia pectoralis (Charpentier, 1825) & specialist & 14 \\
\hline Leucorrhinia rubicunda (Linnaeus, 1758) & specialist & 18 \\
\hline Libellula depressa Linnaeus, 1758 & generalist & 100 \\
\hline Libellula fulva (Müller, 1764) & specialist & 9 \\
\hline Libellula quadrimaculata Linnaeus, 1758 & generalist & 95 \\
\hline Onychgomphus forcipatus (Linnaeus, 1758) & specialist & 18 \\
\hline Ophiogomphus cecilia (Fourcroy, 1785) & specialist & 23 \\
\hline Orthetrum brunneum (Fonscolombe, 1837) & specialist & 36 \\
\hline Orthetrum cancellatum (Linnaeus, 1758) & generalist & 100 \\
\hline Orthetrum coerulescens (Fabricius, 1798) & specialist & 14 \\
\hline Somatochlora arctica (Zetterstedt, 1840) & specialist & 5 \\
\hline Somatochlora flavomaculata (Vander Linden, 1825) & specialist & 9 \\
\hline Somatochlora metallica (Vander Linden, 1825) & generalist & 86 \\
\hline Sympetrum danae (Sulzer, 1776) & generalist & 86 \\
\hline Sympetrum flaveolum (Linnaeus, 1758) & generalist & 86 \\
\hline Sympetrum fonscolombii (Selys, 1840) & specialist & 23 \\
\hline Sympetrum meridionale (Selys, 1841) & specialist & 5 \\
\hline Sympetrum pedemontanum (Müller in Allioni, 1766) & specialist & 23 \\
\hline Sympetrum sanguineum (Müller, 1764) & generalist & 100 \\
\hline Sympetrum striolatum (Charpentier, 1840) & generalist & 86 \\
\hline Sympetrum vulgatum (Linnaeus, 1758) & generalist & 95 \\
\hline
\end{tabular}

